\title{
Enteral ventilation technology to combat severe respiratory failure
}

\author{
Yosuke YONEYAMA ${ }^{1}$, Ryo OKABE ${ }^{1}$ and Takanori TAKEBE ${ }^{1-4 *}$ \\ 1 Institute of Research, Tokyo Medical and Dental University, 1-5-45 Yushima, Bunkyo-ku, Tokyo 113-8510, Japan \\ 2 Division of Gastroenterology, Hepatology \& Nutrition, Developmental Biology, Center for Stem Cell and Organoid Medicine (CuSTOM), \\ Cincinnati Children's Hospital Medical Center, Cincinnati, OH 45229-3039, USA \\ 3 Department of Pediatrics, University of Cincinnati College of Medicine, Cincinnati, OH 45229-3039, USA \\ ${ }^{4}$ Communication Design Center, Advanced Medical Research Center, Yokohama City University Graduate School of Medicine, 3-6 Fukuura, \\ Kanazawa, Yokohama, Kanagawa 236-0004, Japan
}

Key words: enteral ventilation via anus (EVA), respiratory failure, COVID-19, intestinal breathing, perfluorocarbon

\section{Introduction}

In 2020, coronavirus disease 2019 (COVID-19) brought about an unprecedented crisis in humanity. As of July 2021, of the 196 million infected people worldwide, approximately $14 \%$ and $5 \%$ were estimated to be severely ill and fatal, respectively. Sadly, more than 4 million patients died, with an increased fatality rate of $26.9 \%$ in the elderly population. In critically ill patients with respiratory failure, mechanical ventilation and extracorporeal membrane oxygenation are used as standard treatments to provide vital oxygenation. However, in general, their use requires advanced medical resources and highly invasive procedures, potentially making the elderly contraindicated. Thus, developing another supportive oxygenation approach is urgently needed to help countless patients under respiratory distressed conditions.

To this end, our group recently established an "enteral ventilation via anus (EVA)" technique with transanal oxygen delivery by leveraging the highly vascularized distal bowel region [1]. This emerging medical technology can assist respiratory function with minimal invasiveness independent of airway or extracorporeal ventilation. Herein, we discuss the state-of-the-art development and clinical potential of EVA techniques.

\section{Diverse Breathing Modes in Living Organisms}

Four billion years ago, there was no oxygen on the ancient earth, and living organisms evolved in an anaerobic environment. About 2.5 to 2 billion years ago, the oxygen concentration began to increase gradually. The reason behind this is thought to be that cyanobacteria and a variety of plants that emerged later began to produce organic matter and vast amounts of oxygen gas from carbon dioxide and water through photosynthesis. The increase in the concentration of oxygen in the atmosphere provides an aerobic environment that allows organisms to acquire new energy

*Correspondence to: Takebe, T.: takanori.takebe@cchmc.org Received: Jul. 29, 2021; Accepted: Sep. 3, 2021 metabolism, resulting in the flourishing of multicellular and terrestrial organisms with the emergence of various respiration methods [2-11] (Table 1).

The respiratory system of mammals, including humans, is primarily via the lungs; however, by comparing the breathing systems of diverse organisms, various modes of respiration independent of the lungs were acquired during the process of adaptive evolution. For example, in birds and dinosaurs, air flows through the lungs in one direction and is absorbed into the bloodstream. Some frogs and salamanders in Southeast Asia do not have lungs and sustain themselves through cutaneous respiration [2, 4, 5]. Furthermore, among mammals, particular species, such as naked mole rats, obtain energy by activating specialized fructose metabolic pathways under hypoxia; and the genetic approach revealed that sulfur respiration, as well as oxygen, can be utilized for energy metabolism in laboratory mice [6, 7].

Some aquatic organisms acquire accessory modes of respiration that do not involve the gills or skins. Loaches, such as Misgurnus anguillicaudatus, and catfish, such as Corydoras species, use their gut to maintain systemic oxygenation under hypoxic conditions [8-10]. In particular, the loach develops a lung-ventilation-independent intestinal breathing system that works in hindgut area under extremely hypoxic conditions. The histopathological requirements for intestinal respiration include: 1 . abundant capillaries; 2. thinning of the intestinal epithelium; and 3. anatomical proximity to areas of air uptake.

The intestine of the loach is anatomically divided into three regions, cranial to caudal, namely, the foregut, midgut, and hindgut, each of which is approximately $2 \mathrm{~cm}$ in length. Some reports have evaluated the hindgut area responsible for intestinal breathing activity at the molecular and cellular levels. In the 1960s in Japan, for example, histopathological studies on the distance between intestinal epithelial cells and capillaries in the hindgut and comparison with the foregut and midgut showed that the hindgut has a characteristic structure with a more capillary-rich and thinner intestinal epithelium [3, 12]. Recently, extended 
Table 1. Organisms breathe in a wide variety of ways

\begin{tabular}{|c|c|c|c|c|}
\hline $\begin{array}{c}\text { Generic } \\
\text { name }\end{array}$ & Scientific name & $\begin{array}{l}\text { Methods of respiration } \\
\text { and metabolism }\end{array}$ & Method of accessory respiration & Reference \\
\hline Loach & $\begin{array}{l}\text { Misgumus } \\
\text { anguillicandatus etc. }\end{array}$ & Intestinal respiration & $\begin{array}{l}\text { Oxygen is taken into the (posterior) } \\
\text { intestine under hypoxia. }\end{array}$ & Arch Histol Jpn, 1963 [3] etc. \\
\hline Corydoras & Corydoras paleatus & Intestinal respiration & $\begin{array}{l}\text { Oxygen is taken into the (posterior) } \\
\text { intestine under hypoxia. }\end{array}$ & Rev Biol Trop, 2016 [8] \\
\hline $\begin{array}{l}\text { Sea } \\
\text { cucumber }\end{array}$ & $\begin{array}{l}\text { Apostichopus } \\
\text { japonicus }\end{array}$ & Intestinal respiration & $\begin{array}{l}\text { Takes in oxygen from the respiratory tree in } \\
\text { the intestines. }\end{array}$ & PeerJ, 2018 [9] \\
\hline Sea spider & $\begin{array}{l}\text { Colossendeis } \\
\text { megalonyx etc. }\end{array}$ & Intestinal respiration & $\begin{array}{l}\text { Takes in oxygen from the intestines in the } \\
\text { legs. }\end{array}$ & Curr Biol, 2017 [10] \\
\hline $\begin{array}{l}\text { Naked mole } \\
\text { rat }\end{array}$ & $\begin{array}{l}\text { Heterocephalus } \\
\text { glaber }\end{array}$ & Fructose metabolism & $\begin{array}{l}\text { Energy is produced by fructose metabolism } \\
\text { under hypoxic and anoxic conditions. }\end{array}$ & Science, 2017 [6] \\
\hline Mouse & Mus musuclus & Sulfur metabolism & $\begin{array}{l}\text { Use sulfur metabolites for energy } \\
\text { production. }\end{array}$ & Nat Commun, 2017 [7] \\
\hline Frog & $\begin{array}{l}\text { Borbourula } \\
\text { kalimantanensis }\end{array}$ & Cutaneous respiration & $\begin{array}{l}\text { Has no lungs and sustains life through skin } \\
\text { respiration. }\end{array}$ & Curr Biol, 2008 [2] \\
\hline Salamander & $\begin{array}{l}\text { Onychodactylus } \\
\text { japonicus etc. }\end{array}$ & Cutaneous respiration & $\begin{array}{l}\text { Has no lungs and maintains life by } \\
\text { breathing through the mouth and skin. }\end{array}$ & $\begin{array}{l}\text { J Anat, } 2017 \text { [4]; } \\
\text { Proc Biol Sci, } 2018 \text { [5] }\end{array}$ \\
\hline
\end{tabular}

Adapted from reference [11]. Okabe, R., Yoneyama, Y., Takebe, T. Enteral ventilation via anus for severe respiratory failure. Cardioangiology 89, 212-218, 2021 (in Japanese).

molecular analyses have been reported, including analysis of vascular endothelial growth factor (VEGF) expression and signaling molecules related to intestinal breathing in the hindgut, comparative transcriptome analysis of the gut at developmentally different stages before and after the acquisition of intestinal breathing function, and analysis of ammonia secretion capacity along the digestive tract [13-16]. Notably, in adult loaches, the Vegfa and Vegfb genes are highly expressed in the hindgut, and their expression is suppressed when sufficient oxygen is supplied. In addition, the expression of transporters related to digestion, including $\mathrm{H}^{+}$: peptide cotransporter (PEPT1a; Slc15a1), is suppressed specifically in the hindgut compared to the foregut and midgut [17], indicating that loach regulates digestive and respiratory functions in the hindgut to survive under hypoxia.

While some exciting progress has been made in the biology of aquatic organisms, few attempts have been made to translate such mechanisms of intestinal respiration in mammals. Thus, we explored intestinal respiration in mammals and examined the feasibility of supplying oxygen to the blood via the gut.

\section{Mechanism of Enteral Ventilation via the Anus (EVA)}

The loach takes oxygen gas from the atmosphere or oxygen contained in the mud through the hindgut and supplies oxygen to the bloodstream through the thin hindgut mucosa. One of the histopathological findings of the loach hindgut is that the mucosal epithelium is extremely thin, with abundant capillaries in physical proximity to the blood vessels. When we analyzed murine distal rectum corresponding to the hindgut, there are histological similarities in the distal end of the rectum, a region of transition to the anal canal. In this region, the thickness of the epithelium thins abruptly with abundant blood circulation, called the superior rectal venous plexus. We also revealed that in mice, mechanical abrasion to thin the mucosal epithelial layer of the rectal area transiently induced the expression of Vegfa and Anxa1, which are reportedly involved in angiogenesis and epithelial remodeling, respectively, in a similar way as the loach hindgut.

Therefore, we first designed an intestinal gas ventilation (hereafter abbreviated as gas-EVA or g-EVA) system in which pure oxygen is directly administered into the large intestine of mice. The rectum of the mice was mechanically abraded within $4 \mathrm{~cm}$ of the anus side, and pure oxygen gas was then administered to the same area. Using a type I respiratory failure mouse model induced by ventilatory control, we found that the administration of pure oxygen gas to the intestinal lumen improved respiratory symptoms, such as a marked improvement in arterial blood oxygen concentration, the release of hypoxic symptoms in peripheral organs, and a significant improvement of behavioral findings and survival rate (Fig. $1 \mathrm{~A}-\mathrm{C}$ ). Even in a lethal hypoxic state, the g-EVA method allowed survival for more than 50 min and marked improvement in arterial oxygen saturation. These attempts to mimic the histopathological features of the loach hindgut indicated that systemic oxygenation was possible in mice by the administration of pure oxygen to a physically thinned intestine. We also consider the possibility that changes in digestive function, such as a decrease in transporter activity due to abrasion, contribute to successful oxygenation, as observed in loach. Further studies at the physiological and molecular levels are the key to maximizing efficient oxygen in the gut.

We then devised liquid ventilation (hereafter abbreviated as liquid-EVA or l-EVA) in mice and micro mini pigs using perfluorocarbon (PFC) enema towards clinical applications. PFC is a fluorinated compound with excellent oxygen and carbon dioxide transport and dissolution capacities (50 $\mathrm{ml} \mathrm{O}_{2} / \mathrm{dl}$ and $160-210 \mathrm{ml} \mathrm{CO} / \mathrm{dl}$, respectively). In mice, without requiring intestinal abrasion, the ratio of measured 

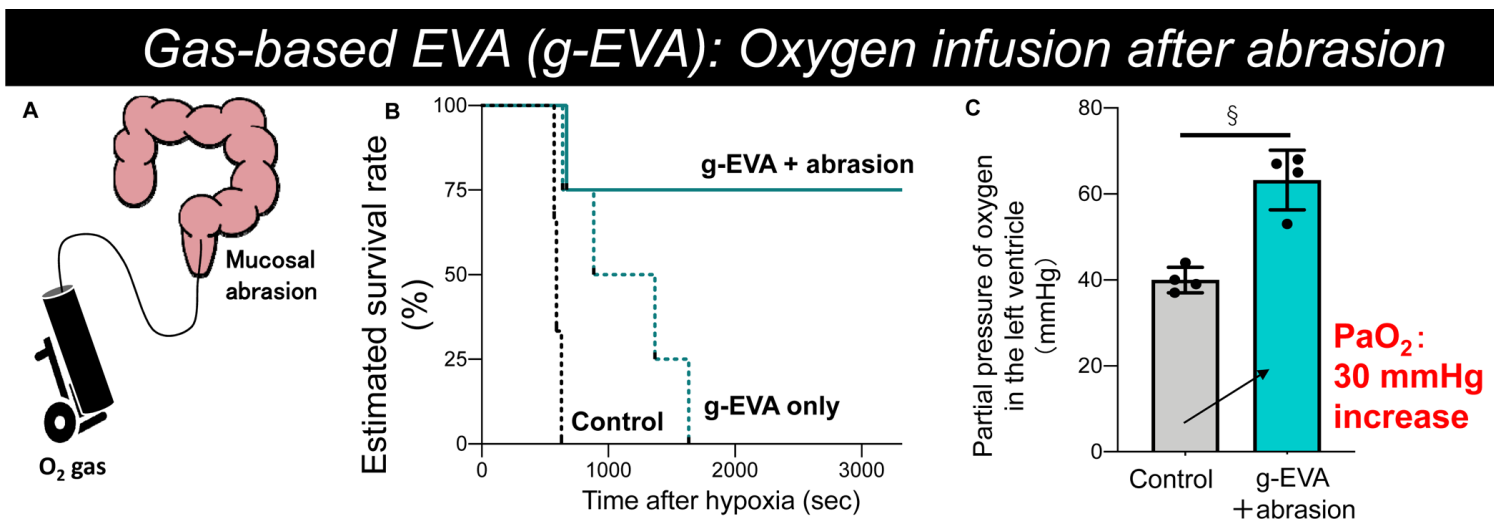

Fig. 1. Resolving fatal hypoxemia by gas-based EVA (g-EVA). Results are cited from [1]. A. Overview of g-EVA with mucosal abrasion. B. Survival rate of control, g-EVA, and g-EVA with mucosal abrasion groups in $8 \%$ lethally hypoxic ventilated mice C. Partial pressure of oxygen in the left ventricle of the heart by $g$-EVA with mucosal abrasion.

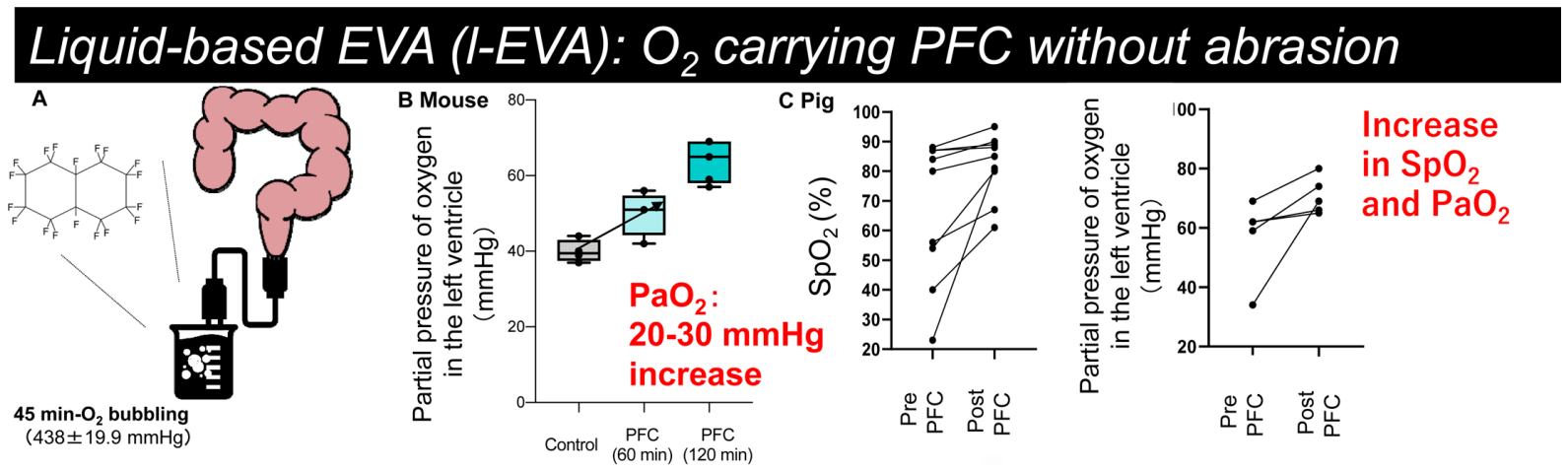

Fig. 2. Resolving fatal hypoxemia using liquid-based EVA (I-EVA). Results are cited from [1]. A. Overview of I-EVA using perfluorocarbon (PFC). B. Improvement of the partial pressure of oxygen in the left ventricle at 60 and 120 min after PFC administration in lethally hypoxic ventilated mice. C. Percutaneous oxygen saturation and partial pressure of oxygen before and after PFC administration in lethally hypoxic-ventilated pigs.

partial pressure of oxygen in the left heart ventricle was approximately 1.6 times higher in the l-EVA treatment group than in the control group $(40.0 \pm 2.94 \mathrm{mmHg}$ and 63.8 $\pm 5.59 \mathrm{mmHg}$, respectively), and the lethal type I respiratory failure was dramatically improved (Fig. 2A, 2B). In micro mini pigs, a single intrarectal administration of PFC improved severe respiratory failure. Furthermore, repeated intrarectal administration of PFC was found to improve respiratory failure for approximately $60 \mathrm{~min}$. The ratio of partial pressure of oxygen measured in arterial blood was approximately 1.2-fold higher in the l-EVA groups (57.2 \pm $13.5 \mathrm{mmHg}$ and $70.8 \pm 6.22 \mathrm{mmHg}$, respectively), and hypoxemia was improved (Fig. 2 C). Thus, the proof of concept was obtained at the large animal level, where the circulating plasma volume is similar to that of humans, suggesting the practicality of this application to patients. The improvement of arterial blood oxygenation demonstrated in our study using mice and micro-mini pigs would be effective in the treatment of patients with severe respiratory failure when applied to humans.

\section{History of Clinical Application and Future Development}

Historically, attempts to improve systemic oxygenation by oxygen gas insufflation into the digestive tract have been made for a long time. For example, in Europe in the 1700s, there is a record that cigarette smoke, aka Tobacco Enema, was put into the rectum of patients who were drowned or suffocated. According to a featured article published at the Lancet magazine, the above-mentioned tobacco enema therapy saved 990 patients [19], until the standard of care, such as ventilators, was established. Later, in the 1950s, the literature indicated that gastric and rectal oxygenation was effective for asphyxia in newborns [18-24]. However, intestine-mediated therapy at that time was poor on a medical basis, and there were risks associated with gas insufflation. To date, no follow-up studies have been conducted [25].

In contrast, after Clark et al. first reported liquid respiration via the airways using PFC with excellent oxygen solubility in 1960, studies with various types of PFC have been reported, including basic experiments on local or systemic oxygenation via the intestine [26-29]. The use of PFC 
to treat hypoxic environments is also being studied in the field of diving medicine, which is used for the treatment of diving diseases as well as for the treatment and prevention of barometric pressure disorders [30]. In addition, PFC has been tested as artificial blood in multiple phases (I, II, and III) clinical trials. Some types of PFC have been administered to more than 35,000 people, and their safety has been confirmed [31-33]. Clinical trials are currently underway for intracranial diseases such as cerebral infarction. As more extensive research is being conducted on PFC as an oxygen carrier, it is expected to deliver a new treatment for ischemic tissues such as ischemic heart disease and cerebral ischemia (ClinicalTrials.gov Identifier: NCT03463551).

A wide variety of clinical applications will be envisioned once intestinal breathing is established. For example, in the field of emergency and intensive care, potential indications, including pneumonia, heart failure, airway burns, bronchial asthma, severe attacks, and cases where neither intubate nor ventilate are expected. Furthermore, although lung transplantation has been established as a curative procedure for patients with chronic respiratory failure, there are multiple exclusion criteria due to limited organ availability. The donor shortage is becoming increasingly serious, and patients on the waiting list need adjunctive respiratory treatment. Thus, there is an unmet need for respiratory support for acute/chronic respiratory failure, such as the need to expand the indications of conventional methods and the search for strategies to protect autologous lungs.

Although there are currently some unsolved issues, including safety and tolerability of PFC enema in humans [34], EVA technology has the potential to act as a bridge to invasive ventilation procedures and, in the long-term, potentially extended towards chronic respiratory problems.

\section{Conflict of Interest}

Y.Y., R.O. and T.T. are inventors for EVA technology and equity holders for EVA Therapeutics, Inc.

\section{References}

1. Okabe, R., Chen Yoshikawa, T. F., Yoneyama, Y., et al. 2021. Mammalian enteral ventilation ameliorates respiratory failure. Med 2: 773-783. [CrossRef]

2. Bickford, D., Iskandar, D. and Barlian, A. 2008. A lungless frog discovered on Borneo. Curr. Biol. 18: R374-R375. [Medline] [CrossRef]

3. Suzuki, Y., Osada, M. and Watanabe, A. 1963. Cytologic and electron microscopic studies on the intestinal respiration of the loach (Misgurnus anguillicaudatus). Arch. Histol. Jpn. 23: 431-446. [Medline] [CrossRef]

4. Lewis, Z. R. and Hanken, J. 2017. Convergent evolutionary reduction of atrial septation in lungless salamanders. J. Anat. 230: 16-29. [Medline] [CrossRef]

5. Lewis, Z. R., Dorantes, J. A. and Hanken, J. 2018. Expression of a novel surfactant protein gene is associated with sites of extrapulmonary respiration in a lungless salamander. Proc. Biol. Sci. 285: 285. [Medline]

6. Park, T. J., Reznick, J., Peterson, B. L., Blass, G., Omerbašić, D., Bennett, N. C., Kuich, P. H. J. L., Zasada, C., Browe, B. M., Hamann, W., Applegate, D. T., Radke, M. H., Kosten, T., Lutermann, H., Gavaghan, V., Eigenbrod, O., Bégay, V., Amoroso, V. G., Govind, V., Minshall, R. D., Smith, E. S. J.,
Larson, J., Gotthardt, M., Kempa, S. and Lewin, G. R. 2017. Fructose-driven glycolysis supports anoxia resistance in the naked mole-rat. Science 356: 307-311. [Medline] [CrossRef]

7. Akaike, T., Ida, T., Wei, F. Y., Nishida, M., Kumagai, Y., Alam, M. M., Ihara, H., Sawa, T., Matsunaga, T., Kasamatsu, S., Nishimura, A., Morita, M., Tomizawa, K., Nishimura, A., Watanabe, S., Inaba, K., Shima, H., Tanuma, N., Jung, M., Fujii, S., Watanabe, Y., Ohmuraya, M., Nagy, P., Feelisch, M., Fukuto, J. M. and Motohashi, H. 2017. CysteinyltRNA synthetase governs cysteine polysulfidation and mitochondrial bioenergetics. Nat. Commun. 8: 1177. [Medline] [CrossRef]

8. Plaul, S. E., Barbeito, C. G. and Díaz, A. O. 2016. Histochemical differences along the intestine of Corydoras paleatus (Siluriformes: Callichthyidae). Rev. Biol. Trop. 64: 327-340. [Medline] [CrossRef]

9. Huo, D., Sun, L., Ru, X., Zhang, L., Lin, C., Liu, S., Xin, X. and Yang, H. 2018. Impact of hypoxia stress on the physiological responses of sea cucumber Apostichopus japonicus: respiration, digestion, immunity and oxidative damage. PeerJ 6: e4651. [Medline] [CrossRef]

10. Woods, H. A., Lane, S. J., Shishido, C., Tobalske, B. W., Arango, C. P. and Moran, A. L. 2017. Respiratory gut peristalsis by sea spiders. Curr. Biol. 27: R638-R639. [Medline] [CrossRef]

11. Okabe, R., Yoneyama, Y. and Takebe, T. 2021. Enteral ventilation via anus for severe respiratory failure. Junkanki Naika 89: 212-218 (in Japanese).

12. Maekawa, K., Fukuda, Y., Okada, J. and Imamura, K. 1968. [Intraepithelial blood capillaries in the air-breathing organs of fish]. Zasshi Tokyo Ika Daigaku 26: 793-799. [Medline]

13. Liu, Y. and Wang, Z. 2017. A Study on Structural Characteristics of Intestinal Tract of the Air-Breathing Loach, Paramisgurnus dabryanus (Sauvage, 1878). Pak. J. Zool. 49: 1223-1230. [CrossRef]

14. Luo, W., Cao, X., Xu, X., Huang, S., Liu, C. and Tomljanovic, T. 2016. Developmental transcriptome analysis and identification of genes involved in formation of intestinal air-breathing function of Dojo loach, Misgurnus anguillicaudatus. Sci. Rep. 6: 31845. [Medline] [CrossRef]

15. Huang, S., Cao, X. and Tian, X. 2016. Transcriptomic analysis of compromise between air-breathing and nutrient uptake of posterior intestine in loach (misgurnus anguillicaudatus), an air-breathing fish. Mar. Biotechnol. (NY) 18: 521-533. [Medline] [CrossRef]

16. Wilson, J. M., Moreira-Silva, J., Delgado, I. L., Ebanks, S. C., Vijayan, M. M., Coimbra, J. and Grosell, M. 2013. Mechanisms of transepithelial ammonia excretion and luminal alkalinization in the gut of an intestinal air-breathing fish, Misgurnus anguilliacaudatus. J. Exp. Biol. 216: 623-632. [Medline]

17. Gonçalves, A. F., Castro, L. F., Pereira-Wilson, C., Coimbra, J. and Wilson, J. M. 2007. Is there a compromise between nutrient uptake and gas exchange in the gut of Misgurnus anguillicaudatus, an intestinal air-breathing fish? Comp. Biochem. Physiol. Part D Genomics Proteomics 2: 345-355. [Medline] [CrossRef]

18. Barrie, H. 1959. Intragastric administration of oxygen. Lancet 1: 884-885. [Medline] [CrossRef]

19. Lawrence, G. 2002. Tobacco smoke enemas. Lancet 359: 1442. [CrossRef]

20. de Boer, A. G., Moolenaar, F., de Leede, L. G. and Breimer, D. D. 1982. Rectal drug administration: clinical pharmacokinetic considerations. Clin. Pharmacokinet. 7: 285-311. [Medline] [CrossRef]

21. Erecinski, K. and Mieroslawski, W. 1958. Treatment of asphyxia of the newborn with the rectal administration of oxygen. Minerva Med. 49: 2675-2678. [Medline]

22. Erecinski, K. and Mieroslawski, W. 1958. Treatment of asphyxia neonatorum by intra-rectal administration of 
oxygen. Pediatr. Pol. 33: 71-75. [Medline]

23. James, L. S., Apgar, V. A., Burnard, E. D. and Moya, F. 1963. Intragastric oxygen and resuscitation of the newborn. Acta Paediatr. (Stockh.) 52: 245-251. [Medline] [CrossRef]

24. Virasoro, J. E., Pellerano, J. C. and Bertelli, S. A. 1959. [Intragastric oxygen therapy: practical technic for administration in the newborn infant]. Sem. Med. 114: 640641. [Medline]

25. Waller, H. K. and Morris, D. 1953. Resuscitation of the newborn with intragastric oxygen; Akerren's method. Lancet 265: 951-953. [Medline] [CrossRef]

26. Clark, L. C. Jr. and Gollan, F. 1966. Survival of mammals breathing organic liquids equilibrated with oxygen at atmospheric pressure. Science 152: 1755-1756. [Medline] [CrossRef]

27. Miyaguchi, N., Nagahiro, I., Kotani, K., Nakanishi, H., Mori, H., Osaragi, T. and Shimizu, N. 2006. Transintestinal systemic oxygenation using perfluorocarbon. Surg. Today 36: 262-266. [Medline] [CrossRef]

28. Papadimitriou, D. K., Pitoulias, G. A., Papaziogas, B. T., Tachtsi, M. D. and Kalaitzis, E. D. 2007. Intraluminal intestinal administration of oxygenated perfluorocarbon improves acid-base and cardiopulmonary parameters after acute mesenteric ischemia. An experimental study in rabbits. Surg. Today 37: 298-304. [Medline] [CrossRef]

29. Hindryckx, P., Devisscher, L., Laukens, D., Venken, K., Peeters, H. and De Vos, M. 2011. Intrarectal administration of oxygenated perfluorodecalin promotes healing of murine colitis by targeting inflammatory hypoxia. Lab. Invest. 91: 1266-1276. [Medline] [CrossRef]

30. Randsøe, T. 2016. Effect of metabolic gases and water vapor, perfluorocarbon emulsions, and nitric oxide on tissue bubbles during decompression sickness. Dan. Med. J. 63: 63. [Medline]

31. Latson, G. W. 2019. Perftoran (vidaphor)-introduction to Western Medicine. Shock 52 Suppl 1: 65-69. [Medline] [CrossRef]

32. Khan, F., Singh, K. and Friedman, M. T. 2020. Artificial blood: the history and current perspectives of blood substitutes. Discoveries (Craiova) 8: e104. [Medline] [CrossRef]

33. Jägers, J., Wrobeln, A. and Ferenz, K. B. 2020. Perfluorocarbonbased oxygen carriers: from physics to physiology. Pflugers Arch. 473: 139-150. [Medline] [CrossRef]

34. Kelly, C. J. 2021. Enteral ventilation via anus: you can hold your breath. Med. 2: 640-641. [CrossRef]. 